\title{
From the Journal, 1853 \\ Something quite definite I have to say
}

... I have something upon my conscience as a writer. Let me indicate precisely how $I$ feel about it. There is something quite definite I have to say, and I have it so much upon my conscience that (as I feel) I dare not die without having uttered it. For the instant I die and so leave this world (so I understand it) I shall in the very same second (so frightfully fast it goesl), in the very same second I shall be infinitely far away, in a different place, where, still within the same second (frightful speed!), the question will be put to me: "Hast thou uttered the definite message quite definitely?" And if I have not done so, what then? . . .

There is something quite definite I have to say. But verily I am not eager to say it. On the contrary, I would so infinitely prefer that another should say it-which, however, would not help me, since (as I understand it) it was and remains my task. But eager to say it I am not; on the contrary, I have wished and craved, and sometimes almost hoped that I might be dispensed from saying it. For it is not a cheerful message, this definite thing, and I cannot but think that there are several persons dear to me to whom it would be unwelcome to hear it said. Above all there is among us a right reverend old man, a consideration which has constantly held me back, laid restraint upon my tongue and upon my pen, a consideration for the highest dignitary of the Church, a man to whom by the memory of a deceased father I felt myself drawn with an almost melancholy affection-and I must think that to him especially it will be very unwelcome that this is said. 


\section{Kierkegaard's}

\section{Attack}

\section{Upon "Christendom"

$$
1854^{-1} 855
$$

TRANSLATED, WITH AN INTRODUCTION, BY WALTER LOWRIE

\section{PRINCETON UNIVERSITY PRESS PRINCETON, NEW JERSEY}


Copyright 1944, by Princeton University Press

This 1968 edition contains a

Supplementary Introduction, by Howard A. Johnson

Copyright $\mathcal{C} 1968$, by Princeton University Press

ISBN 0-69I-01950-9 (paperback edn.)

ISBN 0-691-07102-o (hardcover edn.)

Second Paperback Printing, 1972

Fifth Hardcover Printing, 1972

Tenth Printing, r991

Princeton University Press books are printed on acid-free paper and meet the guidelines for permanence and durability of the Committee on Production Guidelines for Book Longevity of the Council on Library Resources

Printed in the United States of America

$\begin{array}{lll}15 & 16 & 14\end{array}$ 